ISSN $2230-8695$

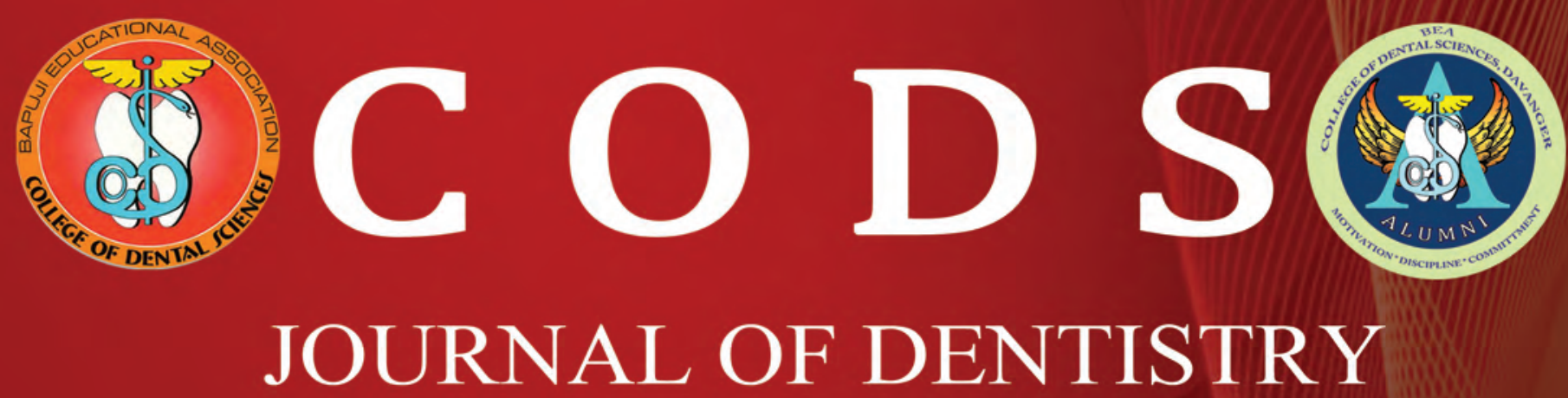

Official Publication of College of Dental Sciences Alumni Association, Davangere.

Volume $6 \cdot$ Issue $1 \bullet 2014$ 


\section{CODS Journal of Dentistry}

Official Publication of College of Dental Sciences Alumni Association, Davanagere

Volume 6, Issue 1, 2014

\section{CONTENTS}

Director's Message

V.V. Subba Reddy

President's Message

Vasundhara Shivanna

Secretary's Message

Praveen S. Basandi

Editorial

Nandini D.B

\section{Original Articles}

Effect of alcohol containing and alcohol free mouth rinses on microhardness of three esthetic restorative materials

Vasundhara Shivanna, Rucha Nilegaonkar

Prevalence and distribution of dental anomalies and fluorosis in a small cohort of

Indian school children and teenagers

Selvamani. M, Praveen S Basandi, Madhushankari G.S

\section{Review Articles}

Paperless dentistry - The future

Mala Ram Manohar, Gajendra Bhansali

Photo activated disinfection in restorative dentistry - A technical review

Deepak B.S, Mallikarjun Goud K, Nishanth P

An overview of occupational hazards in dental practice and preventive measures.

Poorya Naik .D.S, Chetan .S, Gopal Krishna.B.R, Naveen Shamnur

An overview on influences of estrogen and progesterone on periodontium 


\section{CODS Journal of Dentistry}

Official Publication of College of Dental Sciences Alumni Association, Davanagere

\section{Volume 6, Issue 1, 2014}

\section{CONTENTS}

\section{Review Articles}

Dental home - A new approach for child oral health care

Poornima P, Meghna Bajaj, Nagaveni N.B, Roopa K.B, V.V. Subba Reddy

Variants of inferior alveolar nerve block: A review

Anuradha M, Yashavanth Kumar D.S, Harsha .V. Babji, Rahul Seth

\section{Case Reports}

Ellis-van Creveld syndrome affecting siblings: A case report and review

Mamatha G.P, Manisha Jadhav , Rajeshwari G Annigeri, Poornima .P, V.V Subba Reddy

Integrated approach of ceramic and composite veneers in tetracycline

stained teeth: A case report.

Divya K.T, Satish .G

Fibrous dysplasia of right maxilla: A case report and review of literature

Guruprasad .L, Kavita Rao, Uma Devi H.S, Priya N.S

A case report of recurrent herpetic gingivostomatitis; with special reference to the role of cytology in diagnosis

Pramod K Jali, Nandini D.B, Mohan K.P, Madhushankari G.S

Eagle's syndrome with type III segmented styloid process : A case report.

Usha V. A, Mamatha G. P, Maria Priscilla David, 


\title{
Prevalence and distribution of dental anomalies and fluorosis in a small cohort of Indian school children and teenager
}

\author{
Selvamani. $\mathrm{M}^{1} \quad$ Praveen S Basandi² Madhushankari G.S3
}

Reader $^{1,2}$, Professor \& Head $^{3}$

Dept of Oral and Maxillofacial Pathology \& Microbiology College of Dental Sciences, Davangere.

\section{Abstract:}

Objective: The purpose of this study was to determine the prevalence of developmental dental anomalies and fluorosis in small cohort of Indian school children \& teenagers.

Method: A total of 473 school children and teenagers (250 female \& 223 male) of 6 - 17 years were examined clinically for developmental anomalies of teeth such as peg lateral, supernumerary teeth (mesiodens), and talon's cusp. Children were also examined for dental fluorosis.

Result: On examination $1.47 \%$ of the sample population, had at least one developmental dental anomaly. Prevalence of Peg lateral, Mesiodens, and Talon's cusp was $0.63 \%, 0.63 \%$ and $0.21 \%$ respectively while $87.9 \%$ showed fluorosis induced enamel hypoplasia.

Conclusions: the most common dental anomalies was Peg lateral and Mesiodens. The present study also emphasizes the need for de-fluoridation of water in the region, because of high incidence of enamel hypoplasia induced by fluorosis in the study group. Other developmental dental anomalies also differed in prevalence from previous reports, pointing to a possible ethnic variation.

Keywords: Dental anomalies, peg lateral, mesiodens, talon’s cusp, enamel hypoplasia, fluorosis.

\section{Introduction:}

Dental anomalies of teeth are not uncommon. Abnormalities of tooth size, shape, number and structure occur due to disturbance in the development of teeth caused by genetic and environmental factors during the morpho-differentiation or histo-differentiation stages of development. ${ }^{1}$ Although many studies show that hereditary factors are involved in the aetiology. ${ }^{2}$

It is important to treat these anomalies as they can lead to clinical problems which include delayed or incomplete eruption of teeth, occlusal interference, accidental cusp fracture, compromised esthetics, interference with tongue space causing difficulty in speech and mastication, temperomandibular joint pain and dysfunction, malocclusion, periodontal problems

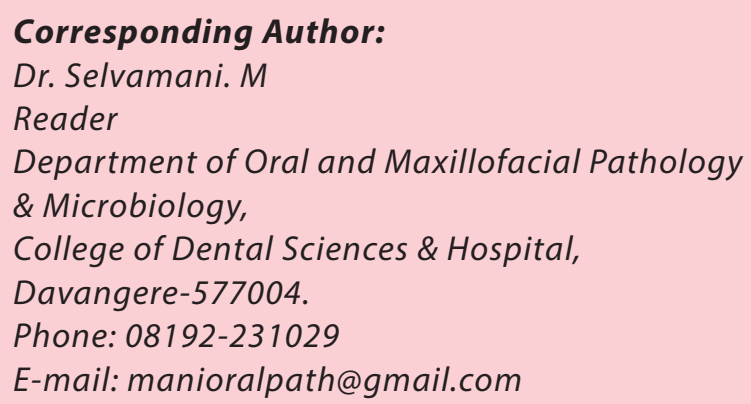

because of excessive occlusal force and increased susceptibility to caries. ${ }^{3,4}$.

Several studies reported variation in the frequency among the prevalence of dental anomalies in different countries and their results are conflicting. The discrepancies in the results could be due to racial differences, variation in sample technique and diagnostic criteria. ${ }^{5-8}$

However, a study representing the South Indian ethnic group has not been done so far. Therefore this study was aimed at establishing the prevalence and distribution of various dental anomalies in a sample South Indian population of school children and teenagers.

A conservative approach to restore teeth with both direct and indirect restorations has been introduced by various authors., ${ }^{3,4}$ The clinical case presented in this article represents a rediscovered philosophy of adhesive and cosmetic dentistry.

\section{Methodology:}

This study was conducted on a total of 473 school children in Davangere district. 250 females and 223 males aged 6-17 years were examined clinically for developmental anomalies of teeth.

The following diagnostic criteria were used for the identifying most common dental anomalies as follows: 
Peg shaped lateral: Any upper lateral incisor demonstrating a reduction in its mesiodistal crown diameter in a cervico-incisal direction ${ }^{9}$.

Mesiodens: A supernumerary tooth present in the premaxilla between the two central incisors. Morphologically it may be cone shaped or tuberculated ${ }^{10}$.

Talon's cusp: A prominent accessory cusp like structure projecting incisally from the cingulum area of an incisor $^{11}$.

Dental Fluorosis: is a hypoplasia or hypomineralization of the tooth enamel or dentin produced by the chronic ingestion of excessive amounts of fluoride during the period when teeth are developing. Depending upon the level of fluoride in the water supply, there is wide range of severity in the appearance of mottled teeth ${ }^{12}$.

\section{Results:}

Among the 473 (250 female and 223 male) school children examined, $1.47 \%$ (7) had developmental anomalies. The distribution by sex was $1.8 \%$ (4) in males and $1.2 \%$ (3) in females. (Table 1)

Out of 473 only one male patient had a Talon's cusp, peg shaped incisor was seen in one male and two females while mesiodens was seen in two males and one female. Prevalence of Peg shaped incisor, mesiodens and Talon's cusp was $0.63 \%$ (3), $0.63 \%$ (3) and $0.21 \%$ (1) respectively in the present study. Fluorosis induced enamel hypoplasia showed a prevalence of $87.9 \%$ (416).

\section{Discussion:}

The occurrence of dental anomalies between our study and previous epidemiological studies showed little difference . These conflicting results could be explained primarily by racial difference and sampling technique as well as by local environmental factors and nutrition.

Previous studies have found the prevalence of Peg lateral to be $0.33 \%$ and $1.51 \% .^{13,14}$ while our study showed $0.63 \%$. These variations are mostly the result of racial and ethnic differences between populations.

Mesiodens are the most common supernumerary teeth seen in maxillary anterior and are usually responsible for the eruption disturbance like delay in eruption of the maxillary anterior permanent teeth. ${ }^{15}$

The prevalence of mesiodens varies between $0.09 \%$ and $2.05 \%$ in different studies and it is reported to be more common in males than in females. ${ }^{16}$ These results are similar to findings of the present study where a prevalence of $0.63 \%$ and a male to female ratio of $2: 1$ was seen. On the contrary, it was not in accordance to a study by Khandelwal V et al, where prevalence of mesiodens was observed to be $3.18 \%{ }^{15}$.

Talon's cusp is a rare dental anomaly in which a cusp-like mass of hard tissue protrudes from the cingulum area of maxillary or mandibular anterior teeth. Incidence is higher in permanent dentition, though talon's cusp can also be observed in primary dentition. ${ }^{17-18}$ The prominent bulge of a talon's cusp may cause interference with occlusion or may result in accidental cusp fractures causing pulpal exposure. ${ }^{18}$ In present study only one male subject showed a talon's cusp on palatal aspect of upper central incisor $(0.21 \%)$ which is similar to the findings of Tulunoglu $\mathrm{O}$ et al who reported a prevalence of $0.04 \%-10 \%{ }^{4}$. Few prevalence studies have been reported in Mexican ${ }^{19}(0.6 \%)$, Malaysian ${ }^{20}(5.2 \%)$, North India ${ }^{21}$ $(0.65 \%)$ and South Indian ${ }^{22}(0.58 \%)$, populations. The prevalence of talon's cusp in the present study was found to be $0.21 \%$. The variation in the talon's cusp prevalence could be explained by variation of the geographic condition among different countries or within a same country or variation in the sample studied or the study design or technique employed.

In present study fluorosis induced enamel hypoplasia showed a prevalence of $87.9 \%$ (416). The study group consisted of children with mixed dentition and teenagers with permanent dentition. The mixed dentition showed increase involvement by enamel hypoplasia in significant number as more permanent teeth erupting as seen with increase in age. The difference in severity of dental fluorosis between the two dentitions has been attributed to placental barrier preventing the passage of fluoride ${ }^{23,24}$ or by the shorter duration of enamel formation and maturation of deciduous dentition ${ }^{24-26}$.

\section{Conclusion: We found that}

- $1.47 \%$ of the children in the group of 473 had at least one developmental dental anomaly.

- Mesiodens and peg shaped incisor were the most common developmental dental anomalies followed by Talon's cusp.

- High incidence of enamel hypoplasia induced by fluorosis was observed in the present study (87.9\%). This emphasizes the need for de-fluoridation of water in the region. The remaining $12.1 \%$ of the subjects not showing fluorosis could be explained possibly by family transfer from areas with low or optimum fluoridation.

- The discrepancies in the results could be due to racial differences, variation in sample technique and diagnostic criteria.

Similar study with larger sample and uniform diagnostic criteria could help in predicting the prevalence of developmental dental anomalies. 
Table 1: Age and sex wise distribution and prevalence of developmental dental anomalies and flourosis:

\begin{tabular}{|c|c|c|c|c|c|c|c|c|c|c|c|c|}
\hline \multirow{2}{*}{$\begin{array}{c}\text { Age } \\
\text { group } \\
\text { (in } \\
\text { years) }\end{array}$} & \multicolumn{2}{|c|}{ No. of patients } & \multicolumn{2}{|c|}{ Peg lateral } & \multicolumn{2}{|c|}{ Mesiodens } & \multicolumn{2}{|c|}{ Talon's cusp } & \multicolumn{2}{|c|}{$\begin{array}{c}\text { Fluoros is induced enamel } \\
\text { hypoplasia }\end{array}$} & \multicolumn{2}{|c|}{ No abnormality } \\
\hline & Male & Female & $\begin{array}{l}\text { Male } \\
\text { n(\%) }\end{array}$ & $\begin{array}{c}\text { Female } \\
\text { n(\%) }\end{array}$ & $\begin{array}{l}\text { Male } \\
\text { n(\%) }\end{array}$ & $\begin{array}{c}\text { Female } \\
\text { n(\%) }\end{array}$ & $\begin{array}{l}\text { Male } \\
\text { n(\%) }\end{array}$ & $\begin{array}{c}\text { Fem } \\
\text { ale } \\
\text { n(\%) }\end{array}$ & Male n(\%) & $\begin{array}{c}\text { Female } \\
\text { n(\%) }\end{array}$ & $\begin{array}{l}\text { Male } \\
\text { n(\%) }\end{array}$ & $\begin{array}{c}\text { Female } \\
\mathbf{n}(\%)\end{array}$ \\
\hline $6-8$ & 25 & 34 & 0 & $1(0.21)$ & $1(0.21)$ & 0 & 0 & 0 & $2(0.42)$ & $3(0.63)$ & $23(4.8)$ & $31(6.5)$ \\
\hline $9-11$ & 26 & 21 & 0 & 0 & 0 & $1(0.21)$ & $1(0.21)$ & 0 & $23(4.8)$ & $21(4.4)$ & $3(0.63)$ & 0 \\
\hline $12-14$ & 123 & 105 & 0 & 0 & 0 & 0 & 0 & 0 & $123(26)$ & $105(22.2)$ & 0 & 0 \\
\hline $15-17$ & 49 & 90 & $1(0.21)$ & $1(0.21)$ & $1(0.21)$ & 0 & 0 & 0 & 49(10.3) & $90(19)$ & 0 & 0 \\
\hline Total & \multicolumn{2}{|c|}{473} & \multicolumn{2}{|c|}{$3(0.63)$} & \multicolumn{2}{|c|}{$3(0.63)$} & \multicolumn{2}{|c|}{$1(0.21)$} & \multicolumn{2}{|c|}{ 416(87.94) } & \multicolumn{2}{|c|}{$57(12.05)$} \\
\hline
\end{tabular}

\section{References:}

1. Proffit WR. The development of orthodontic problems. In: Profit WR, editor. Contemporary orthodontics. 2nd ed. St Louis: Mosby; 1997.p110.

2. Burzynski NJ, Escobar VH. Classification and genetics of numeric anomalies of dentition. Birth Defects: Original Article Series 1983;19(1):95-106.

3. Altug - Atac AT, Erdem D. Prevalence and distribution of dental anomalies in orthodontic patients. American journal of orthodontic and dentofacial orthopedics 2007;131(4):510-14.

4. Tulunoglu O, Cankala DU, Ozdemir RC. Talon's Cusp: Report of four unusual cases. J Indian Soc Pedod Prev Dent 2007;25(1): 52-55.

5. Balit HL. Dental variations among populations. An anthropological view. Dent Clin North Am 1975; 19: 125-39.

6. Ooshima T, Ishido R, Mishima K, Sobue S. The prevalence of developmental anomalies of teeth and their association with tooth size in the primary and permanent dentition of 1650 Japanese children. Int J Pediatr Dent 1996; 6:87-94.

7. Shah RM, Boyd MA, Vakil TF. Studies of permanent tooth anomalies in 7886 Canadian individuals. J Can Dent Assoc 1978; 6: 262-4.

8. Al-Emran S. Prevalence of hypodontia and developmental malformation of permanent teeth in Saudi Arabian school children. $\mathrm{Br} \mathrm{J}$ Orthod 1990;17:115-8

9. Grahnen H. Hypodontia in the permanent dentition: A clinical and genetical investigation. Odont Revy 1956;7:1-100.

10.Rajendran R. Shafer's text book of oral pathology 5th ed Elsvier Churchill- Livingstone 2005

11.Jowharji N, Noonan RG, Tylka JA. An unusal case of dental anomaly: a 'facial' talon cusp. J Dent child 1992; 59:156-58
12.Soben P. Essentials of Preventive and Community Dentistry. 4th ed. New Delhi: Arya (Medi) Publication House; 2009.p.350.

13.Altug - Atac AT, Erdem D. Prevalence and distribution of dental anomalies in orthodontic patients. American journal of orthodontic and dentofacial orthopedics 2007; 131(4):510-14.

14.Clayton JM. Congenital dental anomalies occurring in 3557 children. J Dent Child 1956;23:206-8

15.Khandelwal V, Nayak AU, Naveen RB, Ninawe N, Nayak PA, Sai Prasad SV. Prevalence of mesiodens among six- to seventeen-year-old school going children of Indore. J Indian Soc Pedod Prev Dent 2011;29:288-93.

16.Meighani, Pakdaman. Mesiodens: Diagnosis and Management of Supernumerary (Mesiodens): A Review of the Literature. J Dent Tehran Univ Med Sci 2010;7:41-9.

17.Hattab FN, Yassin OM, al-Nimri KS. Talon cusp-clinical significance and management: case reports. Quintessence Int 1995;26:115-120.

18.Ozcelik B, Atila B. Bilateral Palatal Talon Cusps on Permanent Maxillary Lateral Incisors: A Case Report. Eur J Dent. Jan 2011; 5(1): 113-116.

19.Sedano HO, Carreon Freyre I, Garza de la Garza ML, Gomar Franco CM, Grimaldo Hernandez C, Hernandez Montoya ME, et al. Clinical orodental abnormalities in Mexican children. Oral Surg Oral Med Oral Pathol 1989;68:300-11.

20.Rusmah, Meon. Talon cusp in Malaysia. Aust Dent J 1991;36:11-4.

21.Prabhu RV, Rao PK, Veena KM, Shetty P, Chatra L, Shenai P. Prevalence of talon cusp in Indian population. J Clin Exp Dent 2012;4:e23-7. 
22.Patil SR, Maheshwari S, Khandelwal S. Prevalence of talon cusp in the North Indian population. J Cranio Max Dis 2013;2:114-9.

23.Ericesson Y, Hammarstrom L. Mouse placental transfer of F18 in comparison with Ca45. Acta Odontol Scand 1964; 22:523-28.

24.Gedalia I. Distribution in placenta and foetus. In: Fluorides and human health. WHO, Geneva 1970, p128-34.

25.Hodge HC, Smith FA. In: Simons JH ed. Fluorine chemistry. Vol 4. Academic press, New York - London 1965, p-141-52, 508-11.
26.Smith MC, Smith HV. The occurrence of mottled enamel on the temporary teeth. J Am Dent Assoc 1935; 22:814-17.

\section{How to cite this article:}

Selvamani M, Praveen SB, Madhushankari GS. Prevalence and distribution of dental anomalies and fluorosis in a small cohort of Indian school children and teenagers CODS J Dent 2014;6;9-12

Source of support: Nil. Conflict of interest: None Declared. 